\title{
Negative Effects of Private Tutoring on Stakeholders from Teachers' Perspective
}

\author{
Dr. Ahmet Yuldiz \\ Ministry of Naional Education - Turkey \\ ORCID: 0000-0002-9149-5859 \\ ahmetyildiz58@gmail.com
}

\author{
Assoc. Prof. Dr. Ali Türkdoğan \\ Sivas Cumhuriyet University - Turkey \\ ORCID: 0000-0003-0216-5426 \\ aliturkdogan@hotmail.com
}

\author{
Ekrem Koçak (Teacher) \\ Ministry of Naional Education - Turkey \\ ORCID: 0000-0002-2612-9553 \\ kocak.ekrem@hotmail.com
}

\begin{abstract}
Private lessons, also known as shadow education, are an auxiliary element of the education system both in the world and in our country. The fact that mathematics course requires using many high-level cognitive skills at the same time and the current state of mathematics achievement in central exams are among the reasons why the demand for private lessons for mathematics is higher than for other courses. Conducted studies generally focus on the reasons why students take private lessons. The purpose of this research is to determine the negative effects of the private lesson process on teachers, students, and parents from the perspective of teachers who give private lessons. In the study, descriptive research model was used because of revealing an existing situation. The study group consists of 108 mathematics teachers, who were determined by using the convenient sampling method and had private tutoring experience. The data collection process was carried out with 3 open-ended questions developed by the researchers asking the opinions of the teachers about the negative effects of private lessons on teachers, students and parents. The data of the research were collected online using "Google Form" in the fall semester of the 2020-2021 academic year. The obtained data were analyzed by content analysis method. According to the data obtained, the teachers stated that private lessons can reduce the self-esteem, motivation and interest of the teacher. It has been determined that the private lesson process can cause negativities such as the teacher's being away from formal education, experiencing various health problems, and feeling stress and anxiety. It was determined that the students who took private lessons could not find enough time for their social environment, their stress/anxiety levels increased, and they could distance themselves from formal education and alienate themselves from private lessons. The most common negative effect of private tutoring on parents is temporal and financial difficulties. In addition, private lessons can cause anxiety and stress on the parents. These results were compared with the results of similar studies in the literature and the study was completed by making various suggestions.
\end{abstract}

Keywords: Private tutoring, One-on-one tutoring, Shadow education, Math, Math teacher, Math tutoring

\section{Suggested Citation}

Yıldız, A., Türkdoğan, A. \& Koçak, E. (2022). Negative effects of private tutoring on stakeholders from teachers' perspective, E-International Journal of Educational Research, 13(1), 19-37. DOI: https://doi.org/10.19160/eijer.1016071 


\section{INTRODUCTION}

Education is a process that continues from birth to death. The main purpose of education is to prepare the individual for the future by ensuring that he or she acquires the knowledge and skills that will enable them to adapt to the society they live in. Preparing the individual for the future is a process that requires continuity, long-term, planned, and involves various problems. (Senemoğlu, 2018).

One of the important educational problems in Turkey is the problems encountered in transitions between levels (from primary to secondary, from secondary to higher education). With each passing year, the number of candidates taking entrance exams to higher education increases and the number of those who cannot be placed in higher education programs. So much so that the number of those who took the exam more than once exceeded the number of first-time candidates. Also, frequent changes in secondary education and transition to higher education cause an increase in problems (Aykaç \& Atar, 2014; Erdem, 2014). The root cause of the problem lies in the fact that the education system makes exams important and compulsory and the limitations in access to higher education.

Students can be subjected to different methods for the transition between the levels. These; (i) pass without examination, (ii) maturity test, (iii) entrance exam (central / local, oral / written), (iv) school grades, (v) orientation and (iv) mixed-method using at least two methods (Erdem, 2014; Ergün, 2014; Turan, Çilek \& Yavuz, 2014). It is possible to see almost every one of these methods in the Turkish education system. The transition from primary school to secondary school level in Turkey is without examination. In this context, it can be said that there is no significant problem in the transition from primary school to secondary school (Saracaloğlu, Yakar \& Altay, 2014).

In Turkey, the transition from secondary school to high school level is largely carried out by central exams. Differences in qualifications among high schools can cause competition among secondary school students who want to get a better education. Because a qualified high school can provide an advantage to study in a qualified higher education institution. For example, almost all of the students who are Science High School graduates and approximately $90 \%$ of Anatolian High School graduates can settle in higher education (Kelecioğlu, 2004). The transition from high school to university also takes place through central exams.

Despite their frequent changes, pass exams cannot be dispensed with for both high school placement and higher education (Dinç, Uzun \& Çoban, 2014). These central exams are used to determine the level of achieving the students' goals in the current education level and the transition to the next higher education level.

This situation, which arises from the fact that formal education is exam-oriented, also affects students, teachers, parents, and school administrations, who are education stakeholders (Aylar \& Aksoy, 2015; Kurul et al., 2012). Students who want to be successful in their schools and inter-level transition exams can sometimes receive support from alternative sources outside of the school such as course centers or private tutoring (Baker, 2013; Toprakçı, 2017).

In this sense, the branch in which private lessons are most demanded is perhaps mathematics. Because mathematics requires using many higher-order cognitive skills. Sometimes a student needs to use 4-5 of these high-order thinking skills in the process of solving a problem. The type of question called new generation math questions, which has been widely accepted and included in exams in recent years is one of these kinds of questions. For the reasons stated, most of the time, the lesson in which students fail the most in the central exams is the mathematics lesson. For this reason, the demand for private lessons for mathematics lessons is higher than other lessons. In this sense, it is thought that portraying the negative effects of mathematics private lessons will be pioneering and beneficial in illustrating the situations in other branches. However, private tutoring may also cause some negative effects for students, teachers, and parents. In the literature, it is mentioned that private lessons may cause inequality of opportunity in education and stratification in society (Akdemir \& Kılıç, 2020; Bray \& Lykins, 2012). The perception that private lessons will cause inequality in education causes the prohibition of private lessons in many countries. Because at the secondary school level, a small advantage provided by taking private lessons will cause inequality in entry to a prestigious high school; later on, this effect will also cause inequality in entry to higher education institutions; later on, this 
situation will cause injustices in finding a job; later on, It is thought that it may cause economic and social stratification afterwards (Heyneman, 2011; Southgate, 2009). It is also known that private lessons disrupt the function of the mainstream curriculum in public schools (Southgate, 2009). The financial dimension of private lessons puts pressure on parents. It is clear that private tutoring consumes the time of students, teachers and families. However, there is no literature examining the negative effects of private lessons on students, teachers and parents (Türkdoğan \& Koçak, 2021). It is known that teachers do not feel well ethically because of giving private lessons (Akdemir \& Kılıç, 2020). A student's homework may increase with private lessons, the time he devotes to himself may decrease, and he may be complacent and not be able to give the necessary importance to the school lessons. There is no evidence of these issues in the literature.

When the literature is examined in terms of teachers, it is stated that the teacher earns money from this event. Teaching private lessons may have many contributions other than making money for teachers (Türkdoğan \& Koçak, 2021). Although there is no pressure on the teacher to give private lessons, they may encounter various negativities on the teacher. For example, the time that a teacher devotes to giving private lessons is time that should be devoted to his family and himself. No mention of these negativities was found in the literature. It is known that private lessons cause parents' financial difficulties and have to do extra work to get their children private lessons (Zhang \& Liu, 2016). However, it is not known what kind of problems they encounter beyond these negativities.

The private lesson is also explained with the concept of shadow education in the literature (Bray, 2007; Lee, Park \& Lee, 2009). It is aimed to support formal education by making use of the formal education program in private lessons. In some countries such as Israel and India, private tutoring is legal and organized by state-sponsored non-governmental organizations (Türkan \& Çeliköz, 2018). Private tutoring in South Korea is based on a legal system that is not subsidized by the state (Kim \& Lee, 2010). Demand for private tutoring is high in far-right countries such as Japan, Korea, Singapore, China, India, Sri Lanka, and Bangladesh (Bray \& Lykins, 2012; Kim \& Lee, 2010; Liu, 2012). Although it is a growing phenomenon in the USA and many developed and developing countries, the country does not have an official tutoring policy in the United States (Southgate, 2009).There may be several reasons for the widespread tutoring system. These (Atila \& Özeken, 2015; Bray, 2007; Bray \& Kwo, 2014; Bray \& Lykins, 2012; Büyüköztürk, 2017; Pallegedara \& Mottaleb, 2018; Şad \& Şahiner, 2016; Tan, 2017; Tsiplakides, 2018; Zhang \& Bray, 2018);
$\checkmark$ Inadequacy of the education quality of the countries,
$\checkmark$ Insufficiency of trained and qualified teachers,
$\checkmark$ The desire of students to improve their school grades,
$\checkmark$ Student's desire to receive education in a qualified school,
$\checkmark$ Competition in the exam in the transition between levels,
$\checkmark$ Insufficient teachers' salaries,
$\checkmark$ Difficulty of exams,
$\checkmark$ Population density,
$\checkmark$ Inadequate educational infrastructure,
$\checkmark$ Decrease in the number of children,
$\checkmark$ The density of the curriculum,
$\checkmark$ The thought that taking private lessons will increase the success,
$\checkmark$ Profit-oriented companies that offer private lessons become widespread,

Tutoring, one-on-one or in small groups to meet the needs of students, can contribute positively to students' academic success. It is known that private tutoring and private teaching institutions have a high effect on the success of countries with high success in PISA exams (Domingue \& Briggs, 2009). However, there is also literature stating that it does not increase academic success. On average, there are studies that students in private tutoring perform below other students. (Baker et al., 2001). Tutoring can contribute to the development of teachers' competencies (Walberg, 2016). Private lessons, which are widely available at all levels of education in our country, are ignored (Akdemir \& Kıllıç, 2020).

There are articles in the Constitution of the Republic of Turkey and various laws that prevent civil servants from gaining commercial and additional income (Türkdoğan \& Koçak, 2021; Yerebasmaz, 2011). 
Despite this, private lessons are given by teachers at many levels. However, comprehensive measures are not taken regarding this situation.

In the Turkish education system, many teachers teach private lessons for various reasons, while parents and students take private lessons. For this reason, it is important to consider the subject of private lessons at the academic level and to depict the multifaceted situation in terms of forming its legal basis.

\section{Studies on Private Lessons in Turkey}

In Türkan (2019), "Private Lesson Tendencies of High School Students and Stakeholders 'Opinions on Private Lessons", interviews were held with students, parents, and experts in order to determine the reasons for students' orientation to private lessons. Biçer, Capraro, and Capraro (2013) investigated the orientation of students to private teaching institutions and private lessons in their study titled "Research of Private Mathematics in School Life". In the study, which stated that private lessons create inequality of opportunity, it was recommended by the state to allocate quotas for students with poor financial status in high schools and universities. In addition, teachers were advised not to teach private lessons and to direct students not to take private lessons. Akdemir and Kılıç (2020) stated in their study titled "Examining the reasons why secondary education students take private lessons", that schools cannot meet the academic expectations of students and therefore they turn to private lessons to support their lessons and to be successful in central exams.

Although private lessons are an auxiliary component of the education system, it is seen that the number of studies on this subject in Turkey is low. In the studies, it has been observed that the reasons for the students to take private lessons are emphasized. In other words, no study was found regarding the teachers' views on the private lesson process, in which the incident was not looked at through the eyes of the teacher. In this sense, it is seen that more specific and more in-depth studies are needed. How the tutoring process is experienced; the effects of the daily commute between the places where teachers teach private lessons; If he/she works in any school, its positive or negative effect on his / her duty at school; whether she can spare time for herself or her family when she teaches private lessons; how teachers choose their students; how he teaches his lessons; in what situations he chooses to end classes; In short, the effect of a private lesson on the teacher's life and the perspective of the private lesson should be examined. In addition, the effects of tutoring on stakeholders should be studied from the perspective of both parties and stakeholders. This study will focus on the negative effects of private lessons on teachers, students, and parents. In this context, the research aims to determine the negative effects of tutoring on the stakeholders from the teacher's perspective.

\section{Problem Statement and Sub-problem Sentences}

The thought that today schools do not fulfill their functions adequately has brought along the search for alternatives. It is known that there are educational practices that support academic success in many countries around the world. The most common of these is the one-to-one private lesson, which is considered as an alternative to support school lessons and preparation for exams. In our country, many teachers teach private lessons, and although there are many benefits, a private tutor may face many difficulties, make sacrifices, compromise himself, his time, and his family. This situation creates many negative situations not only for teachers but also for parents and students. The thought of taking away from school lessons and using only a private lesson teacher may occur. In addition, there may be negative reflections on the student, such as the increase in the homework load of the student, and the expectation of absolute success by the parents. The material burden on parents is one of the most striking negativities.

In this sense, the problem sentence of this study is: "What are the negative effects of the private lessons on private lesson stakeholders from the perspective of mathematics teachers?" determined as. To reach detailed information, the following questions were also sought;

1. What are the negative effects of tutoring on a math teacher?

2. What are the negative effects of private tutoring on students who take private lessons?

3. What are the negative effects of private tutoring on parents? 


\section{METHOD}

In this section, the research model, study group, data collection and analysis, validity, and reliability information are included.

\section{Research Model}

This research aims to determine the negative effects of private tutoring on stakeholders. A descriptive research model was used to reveal an existing situation. A descriptive research model is an approach that describes and explains the current or past situation about any subject related to the event, phenomenon, or individual (Mcmillan \& Schumacher, 2010). In this context, in this study, the negative effects of private lessons on students, teachers and parents will be examined from the teacher's point of view.

\section{Study Group}

Easily accessible case sampling, which is one of the purposive sampling methods, was used to determine the study group. In this type of sampling method, the study group is easily accessible and can be selected from people who are suitable for research. Thus, speed and time are gained from the research (Mcmillan \& Schumacher, 2010). In this context, mathematics teachers with private tutoring experience were deemed appropriate to be the participants of the research. The demographic information of the study group is included in Table 1.

Table 1. Demographic information about the sample

\begin{tabular}{|c|c|c|c|c|c|}
\hline Variables & $\mathbf{N}$ & $\%$ & Variables & $\mathbf{N}$ & $\%$ \\
\hline Gender & & & Experience & & \\
\hline Female & 62 & 57 & $0-5$ years & 66 & 61 \\
\hline Male & 46 & 43 & $6-10$ years & 14 & 13 \\
\hline Age & & & 11-15 years & 16 & 15 \\
\hline $20-25$ & 49 & 46 & 16 years or more & 12 & 11 \\
\hline $26-30$ & 22 & 20 & Degree of education & & \\
\hline $31-35$ & 12 & 11 & Bachelor's & 75 & 69 \\
\hline $36-40$ & 18 & 17 & Master's & 30 & 28 \\
\hline 41 or more & 7 & 6 & PhD & 3 & 3 \\
\hline
\end{tabular}

When Table 1 is examined, 108 mathematics teachers participated in the study. 62 of the teachers are female and 46 are male teachers. It is thought that one of the biggest advantages of the researchers is that the sample consists of people who are experts in their field and have experience in private lessons. Because most of the time, the participants gave answers directly to the questions and in items. This facilitated the researchers' interpretation of the data, their coding, the creation of themes and the selection of examples.

\section{Data Collection Tool}

For the data of the research, the online interview form was prepared and used by the researchers. At the beginning of the form, brief information was given to the participants about the scope and process of the research. There is also a confirmation statement stating that they can participate in the study voluntarily. In the first part of the form, demographic information about the participants is included. In the second part of the form, there are three open-ended questions for teachers to determine the negative effects of private lessons on teachers, students, and parents. These questions are listed below.

What do you think are the negative effects of giving private lessons on you/teachers?

$>$ In your opinion, what are the negative effects of taking private lessons on students?

$>$ What do you think are the negative effects of private lessons on parents?

\section{Data Collection Process}

The data of the research were collected online using "Google Form" in the fall semester of the 2020-2021 academic year. The scale was converted to an online form and the link of the form was shared through WhatsApp groups and the social media accounts of the researchers' colleagues. In the posts, 
people were asked to fill out the forms, share the link from their social media accounts, and send them to graduate and doctoral students.

\section{Data Analysis}

The data collected within the scope of the research were analyzed by the content analysis method. The content analysis takes place in three successive stages. First of all, data are gathered and organized. Then the data are encoded and themes are created. In the last stage, the analyzed data are presented as figures, tables, or graphics (Cresswell, 2018).

In this study, the written opinions of the teachers were coded by dividing them into small knowledge categories. Findings obtained with direct quotations supporting/confirming the theme and sub-themes were interpreted. The themes obtained in the analysis process were clustered rationally and compared in terms of contrasts and similarities. In the context of the piece-whole relationship, the relationships between codes were reviewed and common points were tried to be found. The common themes reached through the analysis of teachers, students, and parents' opinions were determined and the findings were rearranged according to these themes. Three expert mathematics educators took part in the creation of the themes. Researchers had met 6 times, 3 face-to-face and 3 online. In these interviews, the themes and codes were determined by considering the sub-problems. Finally, theoretical consistency has been established in a logical order between data. While performing these processes, the percentage of agreement between codes was calculated using the formula developed by Miles and Huberman (2016);

Reliability $=$ Number of Consensus $/$ (Total Consensus + Number of Disagreements) $\times 100$

Initial agreement among researchers was $90 \%$. The final agreement was $95 \%$ when the activities with disagreement were reviewed. This ratio is at an acceptable level (Miles \& Huberman, 2016).

\section{A Sample Data Analysis}

In this section, as an example, the answers given to 3 open-ended questionnaires by a mathematics teacher, male, 25 years old, who has been teaching for 4 years, who taught private lessons for 2 years were analyzed descriptively.

Question1: What do you think are the negative effects of giving private lessons on you/teachers?

1. I know that not every student has the opportunity to have private lessons. This is disturbing me.

2. I have the feeling that I have taken all the responsibility of the student.

3. Sometimes we don't get what we pay for. In other words, sometimes we cannot achieve academic success in students.

4. But absolute success is expected from us. This is a big problem.

When the answers to the 1st question are examined, the teacher thinks that not all students have the opportunity to have private lessons and this situation causes inequality of opportunity in education (line 1). This thought of the teacher corresponds to the "Self-respect" theme (Theme 1). The opinion in the 2 nd line is that all responsibility for the success of the student lies solely with the teacher. From the 3 rd line, it is understood that the teacher does not always get the reward for his labor. In other words, it is understood that students cannot achieve success. The teacher's statements in lines 3 and 4 correspond to the "Stress/Anxiety" theme (Theme 4).

Question 2: In your opinion, what are the negative effects of taking private lessons on your students?

5. Students think that they must be successful. This thought creates extreme anxiety in children.

6. Another source of stress for children is the thought of what will happen if I make a mistake during the lesson. They are very afraid of making mistakes during the lesson.

7. Tiredness and boredom occur in children. Both school lessons, private lessons from mathematics and private lessons from other subjects are tiring for children. And after a while, they get tired of school lessons and private lessons. 
When the answers given to the 2 nd question are examined, the opinions in the 5th and 6 th lines indicate that the students who take private lessons have ideas that they should achieve absolute success and not make mistakes. These thoughts create anxiety and stress in students. For this reason, the teacher's thoughts on lines 5 and 6 correspond to the "Anxiety/stress" theme (Theme 9). In the 7th line, there is the thought that the private lesson creates fatigue and boredom in the students. Therefore, the teacher's answers on the 7th line correspond to the "Health problem" theme (Theme 11).

Question 3: What do you think are the negative effects of private lessons on parents?

8. Parents leave the responsibility directly to the teacher. Thus, they feel that they are relieved of their responsibilities and that they do not have to do anything.

9. Some of the parents may think that the fee paid is too high. And sometimes they say this; sometimes they imply. Even if this fee is low compared to the market, the amount can be higher within the family's means.

10. Parents may be disturbed by the change in course hours.

When the answers to the 3rd question are examined, the statements in the 8th line indicate that the parents leave the responsibility for the student to the teacher who gives private lessons. This view corresponds to the theme (Theme 17) "Parents' problems due to the meaning attached to private lessons". The statements in the 9th line are related to the fact that the fees paid by the parents can force them. The expression in the 10th line states that the parents may experience difficulties due to the changes in the private lesson hours. In this context, the views on the 9th and 10th lines correspond to the theme "Parents are experiencing temporal and financial problem" (Theme 14).

\section{Ethical Permissions of Research}

In this study, all the rules specified to be followed within the scope of the "Higher Education Institutions Scientific Research and Publication Ethics Directive" were complied with. None of the actions specified under the title of "Actions Contrary to Scientific Research and Publication Ethics", which is the second part of the directive, have been taken.

Ethics committee permission information

Name of the committee that made the ethical evaluation: Sivas Cumhuriyet University

Ethics assessment document issue number: 49

\section{RESULTS}

In this section, the negative effects of private lessons on teachers, students, and parents are presented under three main headings. Explanations and comments about themes and sub-themes are included under the table, and the findings were supported by the direct transfer of the answers given by the teachers.

Information on the negative effects of the private lesson on the teacher who teaches the private lesson is given in Table 2 .

In Table 2, seven themes related to the negative effect of a private lesson on the teacher, including self-respect, sense of academic inadequacy, loss of motivation and interest, stress/anxiety, Moving from formal education, time and health problem, are determined as the negative effect of private lessons on teachers.

The "self-respect" theme stated that there was a loss of self-recpect caused by the teacher doing a material job. The teacher experienced a loss of self-respect due to the abuse of the friendly atmosphere between the student and the teacher. Some teachers stated that when they pay more attention to private lesson students than their students at school, they use their conscience and feel uncomfortable and opportunity inequality. A teacher's opinion on this theme is as follows: "Because the tuition fee is higher, putting students in the background and paying more attention to them.", "In addition, since the private lesson is a sincere environment, the reputation of the teacher may be damaged, and even his / her own 
student may be abused.", "The non-working student who does not do it again damages the reputation of the teacher who teaches the lesson..", "It causes me to see myself not as a teacher but as a tradesman.", "I feel like slave laborers who travel house to house, take the money, and do what is required to please the other side..", "I feel that not every student has the same opportunity."

Table 2. Negative effects of private lessons on teachers

\begin{tabular}{|c|c|c|c|}
\hline Theme & Code & $\mathbf{n}$ & f \\
\hline 1 Self-respect & $\begin{array}{l}\text { The teacher thinks that he neglects the students at the school because of the } \\
\text { private lesson. The teacher thinks his dignity has been damaged. } \\
\text { The teacher becomes uncomfortable thinking that it causes inequality of } \\
\text { opportunity. There is a loss of self-confidence in the teacher. }\end{array}$ & 8 & 24,3 \\
\hline $\begin{array}{l}2 \text { Sense of academic } \\
\text { inadequacy }\end{array}$ & The teacher is responsible for student failure & 2 & 6,1 \\
\hline $\begin{array}{l}3 \text { Loss of motivation and } \\
\text { Interest }\end{array}$ & $\begin{array}{l}\text { The teacher may stay away from the profession. The teacher may experience low } \\
\text { motivation. Teacher's endurance in school or private lessons may decrease. }\end{array}$ & 3 & 9,1 \\
\hline 4 Stress / Anxiety & $\begin{array}{l}\text { Parents are waiting for success instantly. There is anxiety in the teacher to pay } \\
\text { back the earnings. Excessive success expectation from the teacher arises. }\end{array}$ & 4 & 12,1 \\
\hline $\begin{array}{l}5 \text { Moving away from } \\
\text { formal education }\end{array}$ & $\begin{array}{l}\text { An understanding of exam-oriented education can be formed in the teacher. } \\
\text { Private tutoring can reduce the efficiency of the teacher. The teacher can get cold } \\
\text { from the school. The teacher can move away from the school environment. }\end{array}$ & 5 & 15,1 \\
\hline 6 Time problem & $\begin{array}{l}\text { The teacher cannot spare time for himself and his family. The teacher may have } \\
\text { to spare time outside of the lesson. The teacher can be disturbed outside of class } \\
\text { time, too. The teacher is experiencing intensity. }\end{array}$ & 4 & 12,1 \\
\hline 7 Health problem & $\begin{array}{l}\text { Illnesses can occur due to fatigue in the teacher. Physical and mental illnesses } \\
\text { can occur at the teacher. The teacher may experience a loss of voice. }\end{array}$ & 7 & 21,2 \\
\hline
\end{tabular}

Under the theme of "Sense of academic inadequacy", students who did not fulfill the tasks assigned by the teachers stated that they failed, and the reason for this situation was attributed to the teacher by the parents. In addition, they stated that they had this feeling if the teacher was incapable of some students. The opinion of a teacher on this theme is as follows: "A student who does not work again damages the reputation of the teacher who teaches the lesson. Although we took private lessons, it seems like he couldn't teach anything. "

In the theme of "Loss of Motivation and Interest", they stated that teachers' exerting too much effort caused low motivation and that new teachers started their duties with difficulties and decreased motivation due to the same reason. The opinion of a teacher regarding this theme is as follows: "We start our profession early. We can get away from the profession because we encounter the difficulties in the teaching profession early. ", "I think it reduces the tolerance because I get intolerant when I try harder and fail to see a concrete success."

Under the theme "Stress / Anxiety", it was stated that the responsibility attributed to teachers creates stress on the teacher. In addition, it was stated that the expectation that the student starting private lessons will be successful immediately affects the teacher negatively. It was stated that students who could not be successful despite all kinds of studies as a result of private lessons worried the teacher. One teacher's view on this theme is: "Confronting a parent's expectation of excellence.", "Students and parents desire high efficiency in a very short time." "Tutoring private lessons to senior students can create anxiety. There is an opinion in the teacher that the child should definitely be successful."

In the theme of "Moving away from formal education", it was stated that private lessons disrupted the primary duties of teachers due to the high financial return. It was stated that the teacher, who was used to lecturing one-to-one, had difficulty in teaching in the classroom environment. In addition, it was stated that the teacher adopted this style of understanding in the classroom environment, as an examoriented expression is usually made in the private lesson. The opinion of a teacher on this theme is as follows: "We start to think exam-oriented and we inevitably guide the children to a racing environment." "When teachers conduct private lessons and school lessons at the same time, either one may be more inefficient." , "If only private lessons are given; It may cause difficulties in classroom control, and may not develop himself in preparing activities for collaborative learning/peer teaching."

In the "Time problem" theme, they stated that teachers could not spare time for themselves and their families and that students or parents were kept busy by calling many times outside of class hours. In addition, they expressed that they were uncomfortable because they could not spare the time that 
they allocated to their students at the school for private lessons. The opinion of a teacher regarding this theme is as follows: "Spending less time with his family and friends, getting away from the social environment.", "Parent/student searching without any hours outside the lesson." "While I am giving private lessons, we allocate more time to the student I teach, while we may not be able to spare enough time for my regular students."

In the theme of "Health Problem", the teachers stated that they were mentally and physically worn out and experienced health problems accordingly. The opinion of a teacher on this theme is as follows: "Assigning extra responsibility, not being busy.", "It gets tiring." , "There is physical and mental fatigue.", "We can experience a loss of voice."

Table 3 contains information about the negative effects of private lessons on students who take private lessons.

Table 3. Negative effects of private lessons on students

\begin{tabular}{lllcc}
\hline Theme & Code & n & f \\
\hline 8 & $\begin{array}{l}\text { Moving away from } \\
\text { formal education }\end{array}$ & $\begin{array}{l}\text { The student is moving away from the classroom environment in the school. The } \\
\text { student gets used to comfort. There is confusion in the student due to the } \\
\text { difference in expression. The student is devaluing the school. The student } \\
\text { devalues education at school. The student is moving away from the } \\
\text { competitive environment. The student is moving away from other classes in the } \\
\text { school. Just being interested in that lesson causes less success in other lessons. }\end{array}$ & 42,9 \\
& & $\begin{array}{l}\text { The family pressures the student. The student is afraid of failure. The student is } \\
\text { losing confidence. The student's motivation is diminishing. The student creates } \\
\text { a feeling of embarrassment towards his family. There is a psychological } \\
\text { pressure on the student. }\end{array}$ & 34,4 \\
\hline 9 & Anxiety/stress & The student is wasting time. There is density in the student. & 3 & 8,5 \\
\hline 10 & Waste of time & The student is tired. & 2 & 5,7 \\
\hline 11 & Health problem & The student is getting asocial. The student can be excluded by their peers. & 2 & 5,7 \\
\hline 12 & Sociability problem & $\begin{array}{l}\text { Moving away from } \\
\text { private lesson }\end{array}$ & The student is getting colder from the private lesson. & 2,8 \\
\hline
\end{tabular}

In Table 3, six themes related to the negative effect of the private lessons on students, namely, Moving away from formal education, anxiety/stress, waste of time, health problem, sociality problem, and moving away from the private lesson, are determined as the negative effects of private lessons on students.

In the theme of "Moving away from formal education", it was stated that the students got used to working one-on-one in private lessons and moved away from the classroom environment, and started not to listen to the lesson taught in formal education. It was also stated that when a student listens to the same lesson from two different teachers, there was confusion due to the differences in expression. The teachers stated that these situations reduced the value of the school and stated that the student's level of interest towards the lessons in the school decreased, they did not participate in the class and they remained away from classroom interaction. The opinion of a teacher regarding this theme is as follows: "The student is completely disconnected from the classroom environment. This factor can also harm the student and make it difficult to learn in society." "Listening to the same course content from different teachers may confuse students due to the difference in expression." "Maybe deprived of peer/group teaching.", "Characteristics such as leadership and taking responsibility do not develop due to lack of group work.", "Decrease in success in other lessons only as a result of giving importance to private lessons".

Under the theme of "Anxiety/stress", it was stated that the parents would put pressure on the student, this pressure would lead the student to stress and negatively affect his / her success and the student would have a feeling of failure. They stated that this situation would decrease the student's motivation and cause him/her to feel worthless. The opinion of a teacher regarding this theme is as follows: "Conflicts may arise when the family thinks that the student will be very good because of taking private lessons and expects it to exceed their capacity..", "There may be pressure on the student. Although the student takes private lessons, fear of failure may occur.", "Depending on the character of the person taking the lesson, there may be a feeling of inadequacy, lack of self-confidence and motivation.", "The student may feel lazy than other friends." 
In the theme of "Waste of time", they stated that the students could not spare time for themselves and those around them. The opinion of a teacher on this theme is as follows: "Time-intensity can occur in students with school and private lessons." "Waste of extra time."

Under the theme of "Health problem", it was stated that the students had health problems and could not rest as a result of excessive effort. The opinion of a teacher regarding this theme is as follows: "Overworking can tire them.", "Much effort."

In the theme of "Sociability problem", he states that students cannot spare time for themselves, in some cases, they are excluded and lonely by their peers. The opinion of a teacher regarding this theme is as follows: "Socialization of the student may decrease as the time left for him/her will decrease.", "The success among the students may cause a positive separation of those who take private lessons and may lead to the exclusion by their peers and loneliness as a result of the exclusion."

In the theme of "Moving away from private lesson", it was stated that the student's taking private lessons and being pressured by the parents kept the student from the private lesson. The opinion of a teacher about this theme is as follows: "Students can be moving away from the private lesson."

Information on the negative effects of private lessons on parents is included in Table 4.

Table 4. Negative effects of private lessons on parents

\begin{tabular}{lll}
\hline Theme & Code & $\mathbf{f}$ \\
\hline 14 & $\begin{array}{l}\text { Parents are experiencing } \\
\text { temporal and financial } \\
\text { problem }\end{array}$ & $\begin{array}{l}\text { Parents are struggling financially. Parents are having trouble in terms } \\
\text { of time. Parents spend money on transportation. Parents are } \\
\text { spending time on transportation. }\end{array}$ \\
\hline $\begin{array}{ll}\text { Stress/anxiety } \\
\end{array}$ & $\begin{array}{l}\text { Parents are worried, "Will my child succeed?" Parents are having } \\
\text { trouble thinking that he is not enough for his child. Parents are forced } \\
\text { to trust a stranger. Parents have trouble hosting their teachers at } \\
\text { home. }\end{array}$ \\
\hline $\begin{array}{ll}\text { Parents' problems during } \\
\text { and after private lessons }\end{array}$ & $\begin{array}{l}\text { The parent is disappointed when the child fails. The parent is } \\
\text { disappointed when he realizes that his child is inadequate. Parents } \\
\text { may have conflicts with their children during the private tutoring } \\
\text { process. Parents can have a conflict with their children after private } \\
\text { lessons. }\end{array}$ \\
\hline $\begin{array}{l}\text { Parents' problems due to } \\
\text { the meaning attached to } \\
\text { private lessons }\end{array}$ & $\begin{array}{l}\text { Parents regard the school as unimportant. Parent throws the } \\
\text { responsibility to the teacher. }\end{array}$ \\
\hline
\end{tabular}

In Table 4, there are "Parents are experiencing temporal and financial problems", "Stress/anxiety", "Parents' problems during and after private lessons", "Parents' problems due to the meaning attached to private lessons" Four themes were determined as the negative effects of private lessons on parents.

They stated that parents are uncomfortable in case of a change in-class hours in the theme of "Parents are experiencing temporal and financial problems", presence of a stranger at home makes the parent uncomfortable and they feel obliged to serve the teacher as a result of the parents seeing the teacher as a guest. The opinion of a teacher on this theme is as follows: "Do not be disturbed by the changes made in the lesson hours.", "If the teacher comes home, then the teacher may have some problems for the family (such as a guest)."

In the parent-oriented theme, they stated that as a result of the parents' assigning their responsibilities to the teacher, they started to take care of their students less, they were disappointed and unhappy as a result of the student's failure. In addition, they stated that they had difficulty paying the tuition fee and financial difficulties. The opinion of a teacher about this theme is as follows: "He thinks that the student will be very successful when he / she takes private lessons, but every student can progress as much as his / her capacity, he / she just does not know that private lessons are not enough for success.". "They may think that they cannot get positive results in line with the financial value of their private tutoring education.". "It saddens the parents that their child has learning difficulties and therefore they receive education with a separate teacher." " In cases where the family is forced to take private lessons for their children, there may still be a conflict between the family." 


\section{DISCUSSION and CONCLUSION}

As a result of the content analysis of the data obtained within the scope of the research, it was concluded that the private lesson had various negative effects on the stakeholders. These negative effects will be discussed separately in the context of teachers, students, and parents, which are the three main stakeholders of the private lesson.

According to the teachers' opinions, the negative effects of the private lesson process on themselves are as follows;

It is seen that the teacher questions his respect for himself because he teaches with the student for a fee. At the same time, student abuse is thought to reduce the teacher's self-respect. These views are thought to be parallel to the literature that private lessons can cause inequality in education (Heyneman, 2011; Southgate, 2009). When the student's failure is attributed to the teacher, the teacher may see himself academically incompetent. The motivation of teachers who devote too much time to private lessons decreases over time and their interest in the teaching profession decreases. The expectation of the success of the student taking private lessons to increase as soon as possible creates stress and anxiety in the teacher. Akdemir and Kılıç (2020) stated that teachers felt pressure due to the perceived private lesson as an ethical problem. In this sense, the decrease in dignity obtained in this study, the questioning of respectability, and the occurrence of stress-anxiety in the teacher are consistent with the results of this study.

The teacher may have difficulties in formal teaching practices over time. In other words, he/she may have difficulties in applying the current curriculum in his/her classroom. The teacher cannot spare enough time for himself, his family, and other students. Various health problems can arise due to the intensity, stress, and anxiety experienced by the teacher. These results are in line with the literature that Southgate (2009) states that the private lessons distorts the implementation of the mainstream curriculum. Teachers claim that their income is low and they need to earn additional income (Tansel \& Bircan-Bodur, 2004). However, it was determined within the scope of this study that teachers experienced some negativities in this process. According to the teachers' opinions, the negative effects of the private lesson process on the students are as follows;

As a result of the students getting used to working one-on-one, they cannot adapt to the classroom environment and may distance themselves from formal education. There is literature showing that private tutoring disrupts the curriculum (functioning) in public schools (Southgate, 2009). This result also compatible with the results obtained in this study on the negative effects of private lessons on teachers (moving away from formal education theme, time theme-health problem theme).

The parents' waiting for the student to be successful immediately causes anxiety and stress in the student. It is known that private lessons are given to students to improve their course grades or exam success (Bray, Kwo \& Jokić, 2016). And this expectation of success can create stress in students. It is predicted that the level of volunteering of students in taking private lessons is important. But there is no literature on the subject. If students find it difficult to take private lessons, it can help to understand the stress and anxiety that occur in the students. In many countries of the world, students are pressured by their families to succeed. Because parents think that successful students can enter good (prestigious) high schools (Bray, 1999). The anxiety and stress that occur in students may also have a parent-related side. In addition, the results of stress/anxiety in students and stress/anxiety in teachers support each other. And also it is thought that this dimension is affected by the parent dimension as well as the teacher dimension.

Students who devote too much time to private lessons experience health problems; They cannot spare enough time for themselves and their environment. This situation causes students to have negativity with their social environment over time. Sixty percent of students placed in prestigious universities in Japan were found to receive private tuition, full-time, for about one year after secondary school (Ono, 2007). It is natural for students who take private tutoring full-time to experience negativity with their social environment. 
Another result obtained from the study is that private lessons have a negative impact on the social life of students. There are various studies in the literature that support the results of the research. Akdemir and Kilıç (2020) stated that students who take private lessons feel a responsibility towards their families and the teacher who teaches the lesson, and they feel pressure on them because they perceive success as a necessity. And this may cause students to disconnect from social life. Chan and Mongkolhutthi (2017) stated that the student taking private lessons could not be in harmony with his/her peers; They stated that they could not develop healthy attitudes because they could not devote enough time to activities that develop conscientious and moral values. Kösterelioğlu (2015) stated that private lessons and similar practices negatively affect the social and psychological aspects of students. Hajar (2018) stated that by taking private lessons, students gain an advantage in the competitive environment, thus reducing their pressure and increasing their self-respect. Tutoring affects students' motivation, interest, and anxiety about the lesson (Bray, 2009; Silova, 2009).

Mischo and Haag (2002) stated that private lessons increase students' motivation. Hong and Park (2012) stated that private lessons have negative effects on students' self-learning. Hof (2014) states that private lessons do not have enough effect on students and therefore it is unnecessary. In this sense, the negativities stated in the literature and the negativities obtained in this study show parallelism.

Another result obtained from the study is that the students become alienated from private lessons over time and do not want to take private lessons. This result seems to be the result of the fact that private lessons cause health problems in students, consume their time, disrupt their sociality and create stress for them. According to the teachers' opinions, the negative effects of the private lesson process on the parents are as follows;

For the private lesson to proceed healthily, it can sometimes be difficult for the parents to transfer time or financial resources. Tansel and Bircan (2004) stated that parents allocate a high budget for private lessons. In some countries, the family allocation for shadow education is almost equal to national expenditure per student for formal education. The Republic of Korea is one of the countries with the highest demand for shadow education and the ratio of money spent on shadow education to national education expenditure is $8 / 10$. It is seen that families from low-income levels who have not taken private lessons rely more on the effect of private lessons (Klemm \& Hollenbach-Biele, 2016). In this case, the money that low-income families allocate for private lessons may be a problem for their home economy.

Whether the student will be successful or not; entrusting the student to a stranger or hosting the teacher at home can cause stress and anxiety for parents. Parents attribute misconceptions to private lessons and regard the school as insignificant; It assigns all responsibility to the teacher and expects absolute success from the student. Dawson (2010) stated that private tutoring practices create distrust towards their schools. The reason for students' distrust of education in public schools may be due to the parents' distrust of education in schools.

When the student fails, the parents may experience disappointment and conflicts with their child. Families relieve themselves in a short time after their children go to the center and become high performers (Bray, 1999). In Germany, it is known that parents prefer private lessons to bring their children together with their peers and to prevent tensions caused by academic problems at home (Guill \& Bos, 2014). In this sense, it is natural for parents to have problems if their children fail. Perhaps the most important factor in the problems experienced during and after private lessons is the excessive expectations of parents from private lessons.

In summary, the results obtained from the study show that private lessons have many negative effects on teachers, students and parents, which are mentioned in the literature or revealed for the first time with this study. Central examination systems, deficiencies in education systems as well as the lack of legal status of private lessons are thought to be effective in these negative effects. 


\section{SUGGESTIONS}

In the light of the results obtained as a result of this study: the researchers think that private tutoring can be converted into an official format. Thus, some negativities of private lessons on teachers, parents, and students can be eliminated. Legal arrangements can be made by examining private tutoring practices abroad. It is known that private lessons are legal in some countries, and private lessons are conducted through non-governmental organizations in some countries (Bray, 1999).

For students with a low-income level, private lessons can be carried out within the scope of courses such as community service practices, which university students take part in too. This can reduce both parents' stress/anxiety and their financial problems.

Although the private lesson is not official, it is a phenomenon that it takes place in practice. Therefore, it is necessary to prepare teachers for the private lesson process. Education about the positive and negative aspects of private tutoring can be given at universities. Training regarding a healthy private lesson process can be provided for teachers, students and parents. Thus, teachers can be informed about how to reduce the stress/anxiety that teachers, students and parents face due to private lessons; they may know that students' motivation may decrease during the tutoring process; they can receive training to help students how to use their time effectively; they can be informed that the lessons at school and the mathematics teacher at school should warn students from time to time that their lessons are important; It will be possible for parents to be aware of the situation of throwing off their responsibilities or having excessive expectations from the teacher.

It is thought that most of the mathematics teachers give private lessons based on their financial income. However, it is seen that giving private lessons has many negative effects on teachers, especially in terms of reducing the time they allocate to their parents and themselves. For this reason, teachers may not be giving private lessons only because they earn financial income. It is thought that reasons other than financial gain may be effective in teachers' giving private lessons. For this reason with the help of the further researches, the reasons of teachers giving private lessons can be investigated more widely.

\section{REFERENCES}

Akdemir, A. B., \& Kılıç, A. (2020). Ortaöğretim öğrencilerinin özel ders alma nedenlerinin incelenmesi. Bolu Abant Izzet Baysal Üniversitesi Eğitim Fakültesi Dergisi, 20(2), 1008-1023. https://doi.org/10.17240/aibuefd.2020..589261

Atila, M., \& Özeken, Ö. (2015). Temel eğitimden ortaöğretime geçiş sınavı: Fen bilimleri öğretmenleri ne düşünüyor? Ondokuz Mayıs Üniversitesi Eğitim Fakültesi Dergisi, 34(1), 124-140.

Aykaç, N., \& Atar, E. (2014, Ocak). Geçmişten günümüze ilköğretimden ortaöğretime geçiş sisteminin değerlendirilmesi. A. Akdoğanbulut İnsan, \& A. Yavuz Akengin (Dü.), Cumhuriyet'in Kuruluşundan Günümüze Eğitimde Kademeler Arası Geçiş ve Yeni Modeller Uluslararası Kongresi içinde (s. 83-104). Antalya: Atatürk Araştırma Merkezi.

Aylar, E., \& Aksoy, H. H. (2015). Dosya: Eğitimde merkezi sınavlar. Eleştirel Pedagoji, 7(42), 54-55.

Baker, C. (2013). Zorunlu eğitime hayır [Insoumission a l'ecole obligatoire]. (A. Sönmezay, Çev.). İstanbul: Ayrıntı Yayınları. (Orijinal kitabın basım tarihi 1985)

Baker, D. P., Akiba, M., LeTendre, G. K., \& Wiseman, A. W. (2001). Worldwide shadow education: Outside-school learning, institutional quality of schooling, and cross-national mathematics achievement. Educational Evaluation and Policy Analysis, 23, 1-17.

Biçer, A., Capraro, M. M., \& Capraro, R. M. (2013). The journey of a middle school student: Explorations of mathematics private tutoring in school life. Sakarya University Journal of Education, 3(3), 123-136.

Bray, T. M. (1999). The shadow education system: Private tutoring and its implications for planners. UNESCO International Institute for Educational Planning.

Bray, M. (2007). The shadow education system: private tutoring and its implications for planners. 2nd ed. UNESCO International Institute for Educational Planning, Paris. https://unesdoc.unesco.org/ark:/48223/pf0000118486 adresinden edinilmiştir. 
Bray, T. M. (2009). Confronting the shadow education system: What government policies for what private tutoring?. United Nations Educational, Scientific and Cultural Organization; International Institute for Educational Planning.

Bray, M., \& Kwo, O. (2014). Regulating private tutoring for public good -policy options for supplementary education in Asia. Comparative Education Research Centre (CERC) No.10 Hong Kong, China.

Bray, M., \& Lykins, C. (2012). Shadow education: Private supplementary tutoring and its implications for policy makers in Asia (No. 9). Asian Development Bank.

Bray, M., Kwo, O., \& Jokić, B. (Eds.). (2016). Researching private supplementary tutoring: Methodological lessons from diverse cultures (Vol. 32). Hong Kong: Comparative Education Research Center

Büyüköztürk, Ş. (2016). Sosyal bilimler için veri analizi el kitabı. Ankara: Pegem Akademi Yayınları.

Chan, C., \& Mongkolhutthi, P. (2017). The factors effecting students choice in studying English at private tutoring schools: A case of Thai upper-secondary school students. Journal of Nusantara Studies, 2(2), 44-52.

Creswell, J. W. (2012). Educational research: Planning, conducting, and evaluating quantitative and qualitative research. Boston: Pearson Education.

Dawson, W. (2009). The tricks of the teacher: Shadow education and corruption in Cambodia. In S. P. Heynemann (Ed.), Buying your way into heaven: Education and corruption in international perspective. Rotterdam: Sense Publishers.

Dinç, E., Uzun, C., \& Çoban, O. (2014, Ocak). Öğretmen ve okul yöneticilerinin kademeler arası geçiş hakkındaki görüşlerinin incelenmesi. A. Akdoğanbulut İnsan, \& A. Yavuz Akengin (Dü.), Cumhuriyet'in Kuruluşundan Günümüze Eğitimde Kademeler Arası Geçiş ve Yeni Modeller Uluslararası Kongresi içinde (s. 293-316). Antalya: Atatürk Araştırma Merkezi.

Domingue, B., \& Briggs, D. C. (2009). Using linear regression and propensity score matching to estimate the effect of coaching on the SAT. Multiple Linear Regression Viewpoints, 35(1), 12-29.

Erdem, A. R. (2014, Ocak). Yükseköğretime geçişin kritiği. A. Akdoğanbulut İnsan, \& A. Yavuz Akengin (Dü.), Cumhuriyet'in Kuruluşundan Günümüze Eğitimde Kademeler Arası Geçiş ve Yeni Modeller Uluslararası Kongresi içinde (s. 851-864). Antalya: Atatürk Araştırma Merkezi.

Ergün, M. (2014, Ocak). Eğitimde kademelerin oluşması ve kademeler arası geçiş düzenlemelerine tarihi bakış. A. Akdoğanbulut İnsan, \& A. Yavuz Akengin (Dü.), Cumhuriyet'in Kuruluşundan Günümüze Eğitimde Kademeler Arası Geçiş ve Yeni Modeller Uluslararası Kongresi içinde (s. 1-40). Antalya: Atatürk Araştırma Merkezi.

Guill, K., \& Bos, W. (2014). Effectiveness of private tutoring in mathematics with regard to subjective and objective indicators of academic achievement. Evidence from a German secondary school sample. Journal for Educational Research Online, 6(1), 34-67.

Hajar, A. (2018). Exploring year 6 pupils' perceptions of private tutoring: Evidence from three mainstream schools in England. Oxford Review of Education, 44(4), 514-531.

Heyneman, S. P. (2011). Private tutoring and social cohesion. Peabody Journal of Education, 86(2), 183-188.

Hof, S. (2014). Does private tutoring work? The effectiveness of private tutoring: A nonparametric bounds analysis. Education Economics, 22(4), 347-366.

Hong, S. C., \& Park, Y. S. (2012). An analysis of the relationship between selfstudy, private tutoring, and selfefficacy on self-regulated learning. Journal of Educational Policy, 9(1), 113-144.

Kelecioğlu, H. (2004). Üniversiteye girişte iki aşamalı sınavda uygulanmış olan öğrenci seçme sınavı puanları ile öğrenci yerleştirme sınavı puanları arasındaki ilişkiler. Eğitim ve Bilim, 29(133).

Kim, S., \& Lee, J. H. (2010). Private tutoring and demand for education in South Korea. Economic Development and Cultural Change, 58(2), 259-296.

Klemm, K., \& Hollenbach-Biele, N. (2016). Nachhilfeunterricht in Deutschland: Ausmaß-Wirkung-Kosten. Bertelsmann Stiftung.

Kösterelioğlu, İ. (2015). Private courses in education or education in private courses? International Online Journal of Educational Sciences, 7(1), 203-218.

Kurul, N., Küçüker, E., Yolcu, H., Özdemir, T., Çokluk, Ö., Baykal, N. S., et al. (2012,Ekim). Kapitalist sistemde öğrenme ve pazar ilişkisi: Metalaştırma, ölçme, standartlaştırma. N. Kurul, T. Öztürkk, \& İ. Metinnam (Dü.), Kamusal Eğitim Sempozyumu içinde (s. 57-92). Ankara: Siyasal Kitabevi.

Lee, C., Park, H., \& Lee, H. (2009). Shadow Education Systems. In Gary Sykes, Barbara Schneider, and David N. Plank (Eds.), Handbook of Education Policy Research. New York: Routledge for the American Educational Research Association, pp.901-919. 
Liu, J. (2012). Does cram schooling matter? Who goes to cram schools? Evidence from Taiwan. International Journal of Educational Development, 32(1), 46-52.

McMillan, J. H., \& Schumacher, S. (2010). Research in Education: Evidence-Based Inquiry, MyEducationLab Series. Pearson.

Miles, M. B., \& Huberman, A. M. (2016). Genişletilmiş bir kaynak kitap: Nitel veri analizi [Qualitative data analysis] (S. Akbaba Altun ve A. Ersoy, Çev.Ed.). Ankara: Pegem Akademi.

Mischo, C., \& Haag, L. (2002). Expansion and effectiveness of private tutoring. European Journal of Psychology of Education, 17(3), 263-73.

Ono, H. (2007). Does examination hell pay off? A cost-benefit analysis of "ronin" and college education in Japan. Economics of Education Review, 26(3), 271-284.

Pallegedara, A., \& Mottaleb, K. A. (2018). Patterns and determinants of private tutoring: The case of Bangladesh households. International Journal of Educational Development, 59, 43-50.

Saracaloğlu, A. S., Yakar, A., \& Altay, B. (2014, Ocak). Türkiye'de ortaokula geçiş sürecinde yaşanan sorunlar ve özel dershaneler: Öğrenci-öğretmen-veli görüşleri (Muğla ve Aydın örnekleri). A. Akdoğanbulut İnsan, \& A. Yavuz Akengin (Dü.), Cumhuriyet'in Kuruluşundan Günümüze Eğitimde Kademeler Arası Geçiş ve Yeni Modeller Uluslararası Kongresi içinde (s. 347-386). Antalya: Atatürk Araştırma Merkezi.

Senemoğlu, N. (2018). Gelişim, öğrenme ve öğretim (25. Basım). Ankara: Anı Yayıncılık.

Silova, I. (Ed.). (2009). Private supplementary tutoring in Central Asia: New opportunities and burdens. Paříz: International Institute for Educational Planning.

Southgate, D. E. (2009). Determinants of shadow education: A cross-national analysis. (Unpublished doctoral dissertation). The Ohio State University, Ohio, USA.

Şad, S. N., \& Şahiner, Y. K. (2016). Temel eğitimden ortaöğretime geçiş (TEOG) sistemine ilişkin öğrenci, öğretmen ve veli görüşleri. Ilköğretim Online, 15(1), 53-76. http://dx.doi.org/10.17051/io.2016.78720

Tan, C. (2017). Private supplementary tutoring and parentocracy in Singapore. Interchange, 48, 315-329.

Tansel, A., \& Bircan, F. (2004). Private tutoring expenditures in Turkey. Discussion paper 2004/13, Turkish Economic Association http://www.tek.org.tr/dosyalar/A-TANSEL-MAY-04.pdf

Toprakçı, E. (2017) Sınıf Yönetimi (3.Baskı). Ankara: Pegem Yayınları

Tsiplakides, L. (2018). Shadow education and social class inequalities in secondary education in Greece: The case of teaching English as a foreign language. International Journal of Sociology of Education, 7(1), 71-93.

Turan, R., Çilek, A., \& Yavuz, İ. (2014, Ocak). Türkiye'de yükseköğretime geçiş sisteminin ortaöğretim sistemi üzerindeki etkileri ve çözüm önerileri. A. Akdoğanbulut İnsan, \& A. Yavuz Akengin (Dü.), Cumhuriyet'in Kuruluşundan Günümüze Eğitimde Kademeler Arası Geçiş ve Yeni Modeller Uluslararası Kongresi içinde (s. 907-929). Antalya: Atatürk Araştırma Merkezi.

Türkan, A., \& Çeliköz, N. (2018). Ortaöğretim öğrencilerine yönelik özel ders eğilim ölçeğinin geçerlik ve güvenirlik çalışması. Uluslararası Bilimsel Araştırmalar Dergisi (IBAD), 3(2), 398-410. https://doi.org/10.21733/ibad.421220

Türkan, A. (2019). Ortaöğretim öğrencilerinin özel ders eğilimleri ve paydaşların özel derse yönelik görüşleri. (Yayımlanmamış doktora tezi). Yıldız Teknik Üniversitesi, İstanbul, Türkiye.

Türkdoğan, A., \& Koçak, E. (2021). Özel dersi yok saymak eğitimde eşitliği sağlamaz. Semra Kıranlı Güngör (Ed). Eğitim Bilimleri Alanında Uluslararası Araştırmalar III içinde, Konya: Eğitim Yayınevi.

Walberg, H. J. (2016). Üretken öğretmenler: Bilgi temelini belirleme [Contemporary issues in curriculum] (N.T. Bümen, Çev.Ed.). Eğitim Programlarında Güncel Sorunlar içinde (ss. 87-102) Ankara: Pegem Akademi Yayınları.

Yerebasmaz, Y. (2011). 657 sayılı devlet memurları kanunu'nun 28. maddesine göre memurların ticaret ve diğer kazanç getirici faaliyetlerde bulunma yasağının kapsamı ve değerlendirilmesi. Journal of Istanbul University Law Faculty, 69(1-2), 1177-1198.

Zhang, W., \& Bray, M. (2018). Equalising schooling, unequalising private supplementary tutoring: Access and tracking through shadow education in China. Oxford Review of Education, 44(2), 221-238.

Zhang, Y., \& Liu, J. (2016). The effectiveness of private tutoring in China with a focus on class-size. International Journal of Educational Development, 46, 35-42. 


\title{
Öğretmenlerin Gözünden Özel Dersin Paydaşlara Olumsuz Etkileri
}

\author{
Dr. Ahmet Yildu \\ Milli Eğitim Bakanlığı - Türkiye \\ ORCID: 0000-0002-9149-5859 \\ ahmetyildiz58@gmail.com
}

\author{
Doç. Dr. Ali Türkdoğan \\ Sivas Cumhuriyet Üniversitesi - Türkiye \\ ORCID: 0000-0003-0216-5426 \\ aliturkdogan@hotmail.com
}

\author{
Ekrem Koçak (Öğretmen) \\ Milli Eğitim Bakanlığı - Türkiye \\ ORCID: 0000-0002-2612-9553 \\ kocak.ekrem@hotmail.com
}

\begin{abstract}
Özet
Özel ders diğer bir adıyla gölge eğitim hem dünyada hem de ülkemizde eğitim sisteminin yardımcı bir unsurudur. Matematik dersinin birçok üst düzey bilişsel beceriyi aynı anda kullanmayı gerektirmesi ve merkezi sınavlardaki matematik başarısının mevcut durumu matematik dersi için özel ders talebinin diğer derslere göre daha yüksek olmasının nedenlerindendir. Gerçekleştirilen araştırmalar genellikle öğrencilerin özel ders alma nedenleri üzerinde durmaktadır. Bu araştırmanın amacı ise özel ders veren öğretmenlerin gözünden özel ders sürecinin öğretmen, öğrenci ve veli üzerindeki olumsuz etkilerini tespit etmektir. Araştırmada var olan bir durumun ortaya çıkarılmasından dolayı betimsel araştırma modeli kullanılmıştır. Çalışma grubunu, uygun örnekleme yönteminden yararlanılarak belirlenen ve özel ders verme tecrübesi olan 108 matematik öğretmeni oluşturmaktadır. Veri toplama işlemi araştırmacılar tarafından geliştirilen, özel dersin öğretmen, ögrrenci ve veli üzerindeki olumsuz etkileri hakkında öğretmen görüşlerini soran üç adet açık uçlu soru ile gerçekleştirilmiştir. Araştırmanın verileri 2020-2021 eğitim-öğretim yılı güz döneminde "Google Form" kullanılarak online bir şekilde toplanmıştır. Elde edilen veriler içerik analizi yöntemi ile incelenmiştir. Elde edilen verilere göre öğretmenler özel dersin öğretmende özsaygı, motivasyon ve ilgiyi azaltabildiğini belirtmişlerdir. Özel ders sürecinin öğretmenin örgün öğretimden uzaklaşması, çeşitli sağlık problemleri yaşaması, stres ve kaygı hissetmesi gibi olumsuzluklara neden olabildiği belirlenmiştir. Özel ders alan ögrrencilerin ise sosyal çevreleri için yeteri kadar zaman bulamadıkları, stres/kaygı düzeylerinin arttığı ve örgün eğitimden uzaklaşıp özel dersten de soğuyabildikleri belirlenmiştir. Özel dersin veli üzerindeki en sık karşılaşılan olumsuz etkisi zamansal ve maddi sıkıntılar olarak ortaya çıkmaktadır. Ayrıca özel ders veli üzerinde de kaygı ve strese neden olabilmektedir. Elde edilen bu sonuçlar literatürdeki benzer çalışmaların sonuçları ile karşılaştırılmış ve çeşitli önerilerde bulunularak çalışma tamamlanmıştır.
\end{abstract}

Keywords: Özel ders, Bire bir özel ders, Gölge eğitim, Matematik, Matematik ögretmeni, Matematik dersi

\section{Önerilen Atıf}

Yıldız, A., Türkdoğan, A. \& Koçak, E. (2022). Negative effects of private tutoring on stakeholders from teachers' perspective, E-Uluslararası Eğitim Araştırmaları Dergisi, 13(1), 19-37. DOI: https://doi.org/10.19160/eijer.1016071 


\section{Genişletilmiş Özet}

Problem: Eğitim, doğumdan ölüme kadar yaşam süresince devam eden bir süreçtir. Eğitimin temel amacı, bireyin yaşadığı topluma uyumunu sağlayacak bilgi ve becerileri edinmesini sağlayarak geleceğe hazırlamaktır (Senemoğlu, 2018). Türkiye'deki önemli eğitim sorunlarından birisi kademeler arası (ilköğretimden ortaöğretime, ortaöğretimden yükseköğretime) geçişlerde karşılaşılan sorunlardır. Her geçen yıl yükseköğretime giriş sınavlarına giren adaylarının sayısı artarken aynı zamanda yükseköğretim programlarına yerleşemeyenlerin de sayısı artmaktadır. Ayrıca ortaöğretim ve yükseköğretime geçiş uygulamalarındaki sık değişiklikler de sorunların artmasına neden olmaktadır (Aykaç ve Atar, 2014; Erdem, 2014).

Öğrenciler kademeler arası geçiş için farklı yöntemlere başvurulabilir. Bunlar; (i) sınavsız geçiş, (ii) olgunluk sınavı, (iii) giriş sınavı (merkezi/yerel, sözlü/yazılı), (iv) okul notları, (v) yönlendirme ve (iv) en az iki yöntemin kullanıldığı karma yöntemdir (Erdem, 2014; Ergün, 2014; Turan, Çilek ve Yavuz, 2014). Türkiye'de ilköğretim kademesinden ortaöğretim kademesine geçiş ise büyük oranda merkezi sınavlarla gerçekleştirilmeye çalışımaktadır. Örgün eğitimin sınav odaklı olması eğitim paydaşları olan öğrencileri, öğretmenleri, velileri ve okul yönetimlerini de etkilemektedir (Aylar ve Aksoy, 2015). Okullarında ve kademeler arası geçiş sınavlarında başarılı olmak isteyen öğrenciler zaman zaman kurs merkezi ya da özel ders gibi okul dışı alternatif kaynaklardan destek alabilmektedirler (Baker, 2013; Toprakçı, 2017).

Bu anlamda özel derslerin en çok talep edildiği branş belki de matematiktir. Çünkü matematik birçok üst düzey bilişsel becerinin kullanılmasını gerektirir. Bazen bir öğrencinin bir problemi çözme sürecinde bu üst düzey düşünme becerilerinin birçoğunu aynı anda kullanması gerekmektedir. Son yıllarda yaygın olarak kabul gören ve sınavlara dahil olan yeni nesil matematik soruları olarak adlandırılan soru türlerinin de matematikte özel ders talebinin nedenlerinden biridir. Belirtilen nedenlerle merkezi sınavlarda öğrencilerin en çok başarısız olduğu ders yine matematik dersidir. Bu sebeple matematik dersi için özel ders talebi diğer derslere göre daha yüksektir. Bu anlamda matematik özel derslerinin olumsuz etkilerinin resmedilmesinin diğer branşlardaki durumların ortaya konulmasında öncü ve faydalı olacağı düşünülmektedir.

Öğrencilerin intiyaçlarını gidermek için bire-bir ya da küçük gruplarla gerçekleştirilen özel ders öğrencilerin akademik başarılarına olumlu katkılar sunabilir. Öğretmenlerin ise yetkinliklerinin gelişmesine katkı sunabilir (Walberg, 2016). Ülkemizde de eğitimin her kademesinde yaygın biçimde bulunan özel ders sistemi görmezden gelinmemesi gereken önemli bir olgudur.

Gerçekleştirilen araştırmalar genellikle öğrencilerin özel ders alma nedenleri üzerinde durmaktadır. Özel ders sürecine öğretmen gözüyle bakan diğer bir ifadeyle özel ders sürecine ilişkin öğretmen görüşlerine ilişkin yeterli düzeyde araştırma literatürde bulunmamaktadır. Bu anlamda daha spesifik ve daha derinlemesine çalışmalara ihtiyaç olduğu görülmektedir.

Ülkemizde birçok öğretmen özel ders vermekte, birçok getirisi olmasına rağmen özel ders veren bir öğretmen aynı zamanda birçok zorlukla da karşılaşabilmekte, fedakârlık yapmakta, kendisinden, zamanından ve ailesinden ödün vermektedir. Bu durum sadece öğretmenler için değil veliler ve öğrenciler için de birçok olumsuz durum oluşturmaktadır. Öğrencinin okul derslerinden uzaklaşması ve sadece özel ders öğretmeninden yararlanma düşüncesi oluşabilmektedir. Ayrıca öğrencinin ödev yükünün artması, veli tarafından mutlak başarı beklenmesi gibi öğrenciye olumsuz yansımaları olabilmektedir. Velilere ise maddiyat yükü en göze çarpan olumsuzlukların başında gelmektedir.

Bu anlamda bu çalışmanın problem cümlesi: "Matematik öğretmenlerinin gözünden özel dersin, özel ders paydaşları üzerindeki olumsuz etkileri nelerdir?" olarak belirlenmiştir.

Yöntem: Bu araştırma, özel dersin özel ders paydaşlarına olumsuz etkilerinin belirlenmesi amaçlanmaktadır. Var olan bir durumun ortaya çıkarılmasından dolayı betimsel araştırma modeli kullanılmıştır (Mcmillan ve Schumacher, 2010). Bu araştırmada betimlenen durum da özel derslerin öğrenci, öğretmen ve veli üzerindeki olumsuz etkileridir.

Çalışma grubunun belirlenmesinde amaçlı örnekleme yöntemlerinden biri olan kolay ulaşılabilir durum örneklemesi kullanıımıştır. Bu tür örnekleme yönteminde çalışma grubu kolay ulaşılabilir ve araştırmaya uygun kişilerden seçilebilir. Böylece araştırmada hız ve zaman kazanılır (Mcmillan ve 
Schumacher, 2010). Bu bağlamda özel ders deneyimine sahip matematik öğretmenlerinin araştırmaya katılmaları uygun görülmüştür. Araştımanın katılımcılarını 62'si kadın 46'sı erkek olmak üzere 108 matematik öğretmeni ouşturmaktadır. Veri toplama aracı olarak araştırmacılar tarafından hazırlanan ve öğretmenlerin özel dersin öğretmene, öğrenciye ve veliye olumsuz etkilerini belirlemeye yönelik 3 adet açık uçlu soru kullanılmıştır. Araştırmanın verileri için çevrimiçi görüşme formu hazırlanmış ve araştırmacılar tarafından kullanılmıştır. Formun başında katıımcılara araştırmanın kapsamı ve süreci hakkında kısa bilgiler verilmiştir.

Araştırma kapsamında toplanan veriler içerik analizi yöntemiyle çözümlenmiştir. Öğretmenlerin yazılı görüşleri küçük bilgi kategorilerine ayrılarak kodlanmıştır. Tema ve alt temaları destekleyen/doğrulayan doğrudan alıntılarla elde edilen bulgular yorumlanmıştır. Analiz sürecinde elde edilen temalar rasyonel olarak kümelenmiş, zıtlıklar ve benzerlikler açısından karşılaştııılmıştır. Temaların oluşturulmasında alanında uzman üç matematik eğitimcisi görev almıştır. Bu işlemler yapıılırken Miles ve Huberman (2016) tarafından geliştirilen formül kullanılarak kodlar arası uyum yüzdesi hesaplanmıştır. Araştırmacılar arasındaki ilk anlaşma \%90 olarak hesaplanmıştır. Anlaşmazlık bulunan faaliyetler incelendiğinde nihai anlaşma \%95 olmuştur. Bu oran kabul edilebilir düzeydedir (Miles ve Huberman, 2016).

Bulgular: Öğretmenlerden "öz-saygı" temasında maddi bir iş yapmalarından kaynaklı öz saygılarını kaybedebildiklerini ifade etmişlerdir. Öğrenci ve öğretmen arasındaki arkadaşça ortamın kötüye kullanımasından rahatsız olduklarını belirtmişlerdir. "Akademik yetersizlik duygusu" temasında öğretmenler verdikleri görevleri yerine getirmeyen öğrencilerin zaman zaman başarısız olduklarını ve velilerin bu durumun sorumlusu olarak öğretmeni gördüklerini belirtmişlerdir. "Motivasyon ve lilgi Kaybı" temasında öğretmenlerin çok fazla çaba sarf etmelerinin kendilerinde motivasyon düşüklüğüne neden olduğunu bu durumun göreve yeni başlayan öğretmenlerin görevlerine uyumda sorun yaşattığını belirtmişlerdir. "Stres / Kaygı" teması altında öğretmenlere atfedilen sorumluluğun öğretmen üzerinde stres yarattığı belirtilmiştir. Ayrıca özel derse başlayan öğrencinin hemen başarılı olacağı beklentisinin öğretmeni olumsuz etkilediği belirtilmiştir. Özel dersler sonucunda her türlü çalışmaya rağmen başarılı olamayan öğrenciler öğretmeni endişelendirmektedir. "Örgün eğitimden uzaklaşma" temasında özel derslerin maddi getirisinin yüksek olması nedeniyle öğretmenlerin asli görevlerini zamanla aksattığı ve birebir ders işlemeye alışkın olan öğretmenin sınıf ortamında ders anlatmakta zorlandığı belirtilmiştir. "Zaman problemi" temasında ise öğretmenlerin kendilerine ve ailelerine zaman ayıramadıklarını, ders saatleri dışında da öğrenci veya velilerin defalarca arayarak meşgul olduklarını belirtmişlerdir. "Sağlık Sorunu" temasında öğretmenler ruhsal ve bedensel olarak yıprandıklarını ve buna bağlı olarak sağlık sorunları yaşadıklarını belirtmişlerdir.

"Örgün eğitimden uzaklaşma" temasında öğrencilerin özel derslerde bire bir çalışmaya alışarak sınıf ortamından uzaklaştıkları ve örgün eğitimde işlenen dersi dinlememeye başladıkları belirtilmiştir. "Kaygı/stres" temasında velilerin öğrenci üzerinde baskı kurdukları, bu baskının da öğrenciyi strese sokarak başarısını olumsuz yönde etkilediği ve öğrencide başarısızık duygusu yaşadığı belirtilmiştir. "Zaman kaybı" temasında ise öğrencilerin kendilerine ve çevrelerine zaman ayıramadıkları belirtilmiştir. "Sağlık sorunu" temasında öğrencilerin sağlık sorunları yaşadıkları ve aşırı efor sonucu dinlenemedikleri belirtilmiştir. "Sosyalleşme sorunu" temasında öğrencilerin kendilerine zaman ayıramadıklarını, bazı durumlarda akranları tarafından dışlandıklarını ve yalnız kaldıklarını belirtmektedir. "Özel dersten uzaklaşma" temasında ise öğrencinin özel ders alması ve velisi tarafından baskı altında tutulmasının öğrenciyi özel dersten alıkoyduğu belirtilmiş̧ir.

Özel dersin veli üzerindeki en sık karşılaşılan olumsuz etkisinin zamansal ve maddi sıkıntılar olarak ortaya çıktığı görülmektedir. Özel ders veli üzerinde kaygı ve strese de neden olabilmektedir. Veliler ders saatinde değişiklik olması durumunda rahatsız olmaktadırlar. Evde bir yabancının bulunmasının veliyi rahatsız etmektedir. Öğretmeni misafir olarak gören veliler kendilerini öğretmene hizmet etmek zorunda hissetmektedirler. Ayrıca velilerin sorumluluklarını öğretmene vermeleri sonucunda öğrencileriyle daha az ilgilenmeye başladıklarını, öğrencinin başarısızlığından dolayı hayal kırıkığına uğradıklarını ve mutsuz olduklarını da belirtmişlerdir.

Öneriler: Araştırmacılar özel ders vermenin resmi bir formata dönüştürülebileceğini düşünmektedirler. Böylece özel derslerin öğretmen, veli ve öğrenciler üzerindeki bazı olumsuzlukları giderilebilir. 
Yurtdışındaki özel ders uygulamaları incelenerek yasal düzenlemeler yapılabilir. Bazı ülkelerde özel derslerin yasal olduğu, bazı ülkelerde ise özel derslerin sivil toplum kuruluşları aracılığıyla yürütüldüğü bilinmektedir (Bray, 1999).

Gelir düzeyi düşük öğrenciler için, üniversite öğrencilerinin de yer aldığı topluma hizmet uygulamaları gibi dersler kapsamında özel ders yapılabilir. Bu, hem ebeveynlerin stresini/kaygısını hem de mali sorunlarını azaltabilir.

Özel ders resmi olmasa da uygulamada yer aldığı bir olgudur. Bu nedenle öğretmenleri özel ders sürecine hazırlamak gerekmektedir. Üniversitelerde özel ders vermenin olumlu ve olumsuz yönleri hakkında eğitim verilebilir. Öğretmen, öğrenci ve velilere sağlıklı bir özel ders süreci ile ilgili eğitimler verilebilir.

Matematik öğretmenlerinin çoğunun maddi gelirlerine göre özel ders verdiği düşünülmektedir. Ancak özel ders vermenin öğretmenler üzerinde özellikle ebeveynlerine ve kendilerine ayırdıkları zamanı azaltması açısından birçok olumsuz etkisinin olduğu görülmektedir. Bu nedenle öğretmenler sadece maddi gelir elde ettikleri için özel ders vermiyor olabilirler. Öğretmenlerin özel ders vermelerinde maddi kazanç dışındaki sebeplerin etkili olabileceği düşünülmektedir. Bu nedenle yapılacak araştırmalarla öğretmenlerin özel ders verme nedenleri daha geniş olarak araştırılabilir. 